\title{
Analisis Pemasaran Karet Sistem Lelang di Kecamatan Kuantan Mudik Kabupaten Kuantan Singingi
}

\author{
Analysis of Rubber Marketing Auction System \\ in Kuantan Mudik Subdistrict Kuantan Singingi District
}

\author{
Dina Kurniati*, Evy Maharani, Susy Edwina \\ Program Studi Agribisnis \\ Fakultas Pertanian Universitas Riau \\ *Kontak penulis: kurniatidina17@gmail.com
}

\begin{abstract}
This study aims to determine the marketing system in the auction market and analyze marketing costs, marketing margins, marketing profits, farmer's share and marketing efficiency at the rubber auction market in Kuantan Mudik District. The sampling method used by farmers is purpusive sampling as many as 23 people and sampling traders using the census method as many as 8 people. The results show that the auction marketing system occurs because of the problems faced by farmers, namely long marketing channels and traders can control the price of bokar due to the low quality of bokar. Farmers participating in the auction market must meet the bokar quality standards set by the Kuantan Singingi Rubber Farmers Association (APKARKUSI) and join a farmer group or Gapoktan. Farmers have limitations in marketing bokar directly to factories, therefore farmers involve marketing agencies. Rubber marketing channels in the auction market are started from farmers-big traders-factories. Farmers who participate in the auction market are subject to a 5\% reduction in bokar volume consisting of 3\% depreciation, $1 \%$ transportation costs and $1 \%$ group operating costs. The selling price of bokar in July 2020 received by farmers was $R p 7.367,50 / \mathrm{kg}$, total marketing cost was $R p 1.316,56 / \mathrm{kg}$, marketing margin was Rp1.596,25/kg, marketing profit was Rp229,69/kg, farmer's share $82,19 \%$ and $14,69 \%$ marketing efficiency. This auction marketing system is efficiently used by farmers in the bokar marketing process in Kuantan Mudik District, because efficiency below 50\% means the lower the percentage of marketing efficiency, the more efficient marketing.
\end{abstract}

Keywords: marketing; auction; rubber; farmer; efficiency.

\begin{abstract}
Abstrak
Penelitian ini memiliki tujuan untuk mengetahui sistem pemasaran pada pasar lelang dan menganalisis biaya pemasaran, margin pemasaran, keuntungan pemasaran, bagian yang diterima petani dan efisiensi pemasaran pada pasar lelang karet di Kecamatan Kuantan Mudik. Metode pengambilan sampel petani secara purpusive sampling sebanyak 23 orang dan pengambilan sampel pedagang dengan menggunakan metode sensus sebanyak 8 orang. Hasil penelitian menunjukan sistem pemasaran lelang terjadi karena permasalahan yang dihadapi petani yaitu saluran pemasaran yang panjang dan pedagang bisa mengendalikan harga bokar dikarenakan mutu bokar rendah. Petani yang mengikuti pasar lelang harus memenuhi standar mutu bokar yang ditetapkan Asosiasi Petani Karet Kuantan Singingi (APKARKUSI) dan tergabung kedalam kelompok tani atau gapoktan. Petani memiliki keterbatasan dalam memasarkan bokar langsung ke pabrik, oleh sebab itu petani melibatkan lembaga pemasaran. Saluran pemasaran karet pada pasar lelang di mulai dari petani-pedagang besar-pabrik. Petani yang mengikuti pasar lelang dilakukan pemotongan volume bokar sebesar 5\% yang terdiri 3\% penyusutan, $1 \%$ biaya transportasi dan $1 \%$ biaya operasional kelompok. Harga jual bokar pada Bulan Juli 2020 yang diterima petani sebesar Rp7.367,50/kg, total biaya pemasaran $\mathrm{Rp} 1.316,56 / \mathrm{kg}$, margin pemasaran Rp1.596,25/kg, keuntungan pemasaran Rp229,69/kg, farmer's share $82,19 \%$ dan efisiensi pemasaran 14,69\%. Sistem pemasaran lelang ini efisien
\end{abstract}


digunakan petani dalam proses pemasaran bokar yang ada di Kecamatan Kuantan Mudik, dikarenakan efisiesi dibawah $50 \%$ bearti semakin rendah persentase efisiensi pemasaran maka pemasaran semakin efisien.

Kata kunci: pemasaran; lelang; karet; petani; efisiensi.

\section{Pendahuluan}

Indonesia sebagai negara agraris yang bergantung pada sektor pertanian. Sektor pertanian merupakan salah satu sektor penting dalam perekonomian nasional terutama subsektor perkebunan. Subsektor perkebunan mempunyai kontribusi dalam penciptaan nilai tambah terhadap produk domestik bruto (PDB). Pemerintah mulai memacu pertumbuhan dan perkembangan beberapa komoditi potensial, dikarenakan subsektor perkebunan mampu menyediakan lapangan kerja bagi masyarakat. Komoditi perkebunan yang berpotensial untuk dikembangkan di Indonesia yaitu kelapa sawit, karet, kelapa, kakao, teh dan tebu (Badan Pusat Statistik, 2019).

Perkebunan karet terluas di Provinsi Riau pada tahun 2018 terdapat di Kabupaten Kuantan Singingi dengan luas 138.908,05 ha dan produksi sebanyak 83.664.05 ton. Kecamatan yang mengikuti pasar lelang di Kabupaten Kuantan Singingi yaitu Kecamatan Kuantan Mudik memiliki luas perkebunan seluas 9.797,40 ha dengan produksi 7.492,12 ton (Badan Pusat Statistik, 2019). Sistem pemasaran lelang terjadi karena pada sistem pemasaran sebelumnya pedagang melakukan pengendalian harga bokar, informasi harga hanya melalui pedagang dan rantai pemasaran yang panjang dilalui petani menyebabkan harga yang diterima lebih rendah dibandingkan pasar lelang. Oleh karena itu pedagang dengan mudah memainkan harga yang didapatkan oleh petani dan hanya memikirkan keuntungan yang didapat oleh pedagang tersebut (Fatah, 2018).

Sistem pemasaran lelang sangat menguntungkan petani berupa lembaga pemasaran yang dilalui semakin pendek dan harga yang didapat petani sesuai dengan pasar lelang, namun petani juga harus meningkatkan produksi bokar yang dilihat dari kualitas dan kuantitas bokar. Petani karet di Kabupaten Kuantan Singingi bersatu dalam satu lembaga pemasaran yang didukung oleh Dinas Pertanian Kabupaten Kuantan Singingi dengan nama Asosiasi Petani Karet Kuantan Singingi (APKARKUSI). APKARKUSI terdiri dari kelompok tani atau gapoktan yang ada dibeberapa kecamatan di Kabupaten Kuantan Singingi. Kecamatan Kuantan Mudik merupakan salah satu kecamatan yang bergabung dalam APKARKUSI dengan enam kelompok tani yang beranggotakan 180 orang (APKARKUSI, 2020).

Petani yang mengikuti pasar lelang harus bergabung dengan kelompok tani atau gapoktan yang ada di masing-masing kecamatan. Pasar lelang yang ikuti oleh petani mempunyai syarat bokar yang ditetapkan APKARKUSI. Berikut syarat bokar yang harus dipenuhi oleh petani: bokar dalam keadaan kering dan tidak direndam, bokar dalam keadaan bersih dan tidak boleh terdapat kotoran dalam bentuk apapun, pembeku yang dibenarkan (asam semut, cuka, dan deorub) dan kondisi bokar dalam keadaan sehat dan padat.

Penetapan harga bokar dapat dilihat dari sicom (Singapore Commodity Exchange) harga karet saat ini dan kurs terhadap rupiah. Sicom adalah situs di google yang memberikan informasi mengenai harga bokar. Harga bokar disesuaikan dengan mutu 
K3 (kadar karet kering, kadar karet kotor dan kadar ketebalan karet). Harga bokar pada sistem pemasaran lelang yang dilakukan di APKARKUSI berkisar antara Rp8.000,00 (1 Oktober 2019) sampai Rp9.980,00 (26 Mei 2019 dari Data Rekap Penjualan Bokar APKARKUSI). Pelaksanaan pasar lelang dilakukan sekali seminggu pada Hari Minggu.

Berdasarkan uarain tersebut sistem pemasaran lelang yang dapat menguntungkan petani, namun masih banyak petani yang belum bergabung dalam sistem pemasaran lelang. Oleh karena itu penelitian ini diarahkan agar petani lebih mengetetahui sistem pemasaran pada pasar lelang dan analisis pemasaran yg terdapat pada pasar lelang. Penelitian terdapat dua tujuan yaitu yang pertama untuk mengetahui sistem pemasaran lelang di Kabupaten Kuantan Singingi dan tujuan kedua untuk menganalisis biaya pemasaran, margin pemasaran, keuntungan pemasaran, bagian yang diterima petani dan efisiensi pemasaran pada pasar lelang karet di Kecamatan Kuantan Mudik.

\section{Metode Penelitian}

Penelitian ini dilaksanakan di Kecamatan Kuantan Mudik Kabupaten Kuantan Singingi. Penentuan lokasi penelitian dilakukan secara sengaja karena telah berhasil mengikuti sistem pemasaran lelang di APKARKUSI. Penelitian ini menggunakan metoda survei dengan pengumpul data berupa kuesioner. Responden petani dipilih secara purpusive sampling sebanyak 23 petani dan pengambilan sampel pedagang dengan metode sensus sebanyak 8 pedagang besar. Jenis data yang digunakan data primer yang didapat dilapangan melalui kuesioner dan data sekunder didapat dari BPS kabupaten, BPP kabupaten dan APKARKUSI. berikut:

Analisis data yang digunakan dalam penelitian ini adalah sebagai

a. Margin pemasaran

Besarnya margin pemasaran dapat dihitung menggunakan rumus (Sudiyono, 2004), sebagai berikut:

Keterangan:

MP : Margin Pemasaran ( $\mathrm{Rp} / \mathrm{kg} / \mathrm{bulan})$

Pr : Harga ditingkat pengecer ( $\mathrm{Rp} / \mathrm{kg} / \mathrm{bulan})$

Pf : Harga ditingkat petani ( $\mathrm{Rp} / \mathrm{kg} /$ bulan)

b. Keuntungan pemasaran

Menurut Soekartawi (2002) keuntungan dapat dirumuskan:

Keterangan:

$$
\Pi=\mathrm{MP}-\mathrm{BP}
$$

$\Pi=$ Keuntungan pemasaran $(\mathrm{Rp} / \mathrm{kg} / \mathrm{bulan})$

$\mathrm{MP}=$ Margin pemasaran $(\mathrm{Rp} / \mathrm{kg} / \mathrm{bulan})$

$\mathrm{BP}=$ Biaya Pemasaran $(\mathrm{Rp} / \mathrm{kg} /$ bulan $)$

c. Farmer's share

Asmarantaka (2014) merumuskan:

Keterangan:

$$
\mathrm{Fs}=\frac{\mathrm{Pf}}{\operatorname{Pr}} \times 100 \%
$$

Fs = Bagian harga yang diterima petani karet (\%)

Pf $=$ Harga karet di tingkat petani $(\mathrm{Rp} / \mathrm{kg} /$ bulan $)$ 
Pr = Harga karet di tingkat konsumen akhir $(\mathrm{Rp} / \mathrm{kg} / \mathrm{bulan})$

d. Efisiensi pemasaran

Menurut Soekartawi (2002) digunakan rumus:

$$
\mathrm{EP}=\frac{T B}{T N P} X 100 \%
$$

Keterangan :

$$
\begin{array}{ll}
\mathrm{EP} & =\text { Efisiensi pemasaran }(\%) \\
\mathrm{TB} & =\text { Total Biaya Pengencer }(\mathrm{Rp} / \mathrm{kg} / \text { bulan }) \\
\mathrm{TNP} & =\text { Total Nilai Produk yang dibayarkan }(\mathrm{Rp} / \mathrm{kg} / \mathrm{bulan})
\end{array}
$$

\section{Hasil dan Pembahasan}

\section{Responden petani lelang}

Petani yang mengikuti pasar lelang di Kecamatan Kuantan Mudik sebanyak 23 orang yang terdiri dari Desa Sangau dengan Kelompok Tani Sangau Makmur dengan jumlah petani sebanyak 6 orang dan Desa Pebaun Hilir dengan Gapoktan Tandikek Indah dengan jumlah petani sebanyak 17 orang. Jumlah petani berdasarkan jenis kelamin laki-laki sebanyak 20 orang $(86,96 \%)$ dan perempuan sebanyak 3 orang $(13,04 \%)$. Umur produktif sebesar 20 orang $(86,96 \%)$ dan tingkat umur tidak produktif sebanyak 3 orang (13,04\%). Tingkat pendidikan petani lelang paling sedikit tamat SD sebanyak 4 orang dan paling banyak tamat SMA sebanyak 8 orang. Pengalaman berusahatani paling sedikit tanaman berumur 11-20 tahun sebanyak 4 orang dan paling banyak berada pada pengalaman $>20$ tahun sebanyak 14 orang.

\section{Responden pedagang besar}

Sampel pedagang besar pada pasar lelang berjumlah 8 orang dengan jenis kelamin laki-laki. Rata-rata umur pedagang besar adalah umur produktif. Pedagang besar memiliki pabrik tujuan yang berbeda-beda. Berikut tujuan pabrik setiap pedagang besar 1 menjual bokar ke PT. Kilang 5 Gunung, pedagang besar 2 menjual bokar ke PT. Wipolimex, pedagang besar 3 menjual bokar ke PT. Bangkinang, pedagang besar 4 menjual bokar ke PT. Batang Hari Barisan, pedagang besar 5 menjual bokar ke PT. Tirta Sari, pedagang besar 6 dan 7 menjual bokar ke PT. Teluk Luas dan pedagang besar 8 menjual bokar ke PT. Kapuas Besar.

\section{Sistem pemasaran karet pasar lelang}

Pasar lelang sudah terbentuk sejak tahun 2007 yang dimulai di Kecamatan Kuantan Tengah yang disebut pasar lelang gapoktan. Pasar lelang gapoktan dilakukan di kecamatan dengan syarat dan ketentuan yang sudah ditetapkan oleh setiap kelompok tani atau gapoktan. Sejalan dengan temuaan Vadilla (2012) menyatakan bahwa prosedur dan tatacara pelaksanaan lelang berdasarkan ketentuan yang ada pada pasar lelang. Semua aturan yang telah diberikan pihak penyelenggara harus ditaati oleh semua anggota lelang jika tidak ditaati akan dikeluarkan dan tidak boleh mengikuti pelelangan.

Perkembangan pasar lelang terus meluas ke kecamatan lain dan membuat Dinas Pertanian Kabupaten Kuantan Singingi membentuk lembaga pemasaran tingkat kabupaten yang bernama Asosiasi Petani Karet Kuantan Singingi (APKARKUSI). 
APKARKUSI memiliki tujuan untuk keseragaman mutu bokar, peningkatan skala produksi dan ekonomi serta pemasaran bokar yang dilakukan secara bersamaan satu waktu, satu tempat dan satu harga. APKARKUSI dibentuk pada tanggal 19 Juli 2018 yang bertempat di kantor Dinas Pertanian Kabupaten Kuantan Singingi yang dihadiri oleh 3 UPPB, 3 gapoktan dan 5 kelompok tani. Pasar lelang gapoktan ataupun APKARKUSI dalam proses pelaksanaan pelelangan bokar hampir sama yang membeda tempat dan syarat bokar sudah ditetapkan setiap kelompok tani atau gapoktan atau APKARKUSI.

Pasar lelang mampu menjembatani petani dalam memasarkan bokar dan harga yang diputuskan sesuai dengan mekanisme pasar persaingan sempurna yang artinya tidak dipengaruhi oleh penjual ataupun pembeli. Peran APKARKUSI mampu memberikan informasi serta menyeimbangkan struktur komunikasi antar petani dan pedagang. Manfaat yang didapat petani dalam memasarkan bokar melalui APKARKUSI yaitu mendapatkan bantuan dari pemerintah berupa bibit dan alat yang digunakan dalam penyadapan, mendapat pelatihan budidaya karet, pelatihan pemasanen sesuai standard operating procedure (SOP) dan pembagian uang simpanan kelompok. Ahmadi, N \& Pratama (2017) mengatakan bahwa faktor-faktor yang mempengaruhi atau menyebabkan petani menjual karet ke pasar lelang diantarannya informasi harga dan timbangan lebih transparan, harga beli bokar lebih tinggi, di luar pasar lelang membeli bokar dengan harga yang rendah karena tidak menilai berdasarkan kualitas bokar, ada potongan harga dan timbangan disebut basia atau penyusutan.

Petani yang mengikuti pasar lelang harus bergabung dalam kelompok tani ataupun gapoktan dan mengikuti standar bokar. Berikut syarat bokar yang ditetapkan oleh APKARKUSI:

1. Bokar dalam keadaan kering dan tidak basah.

2. Bokar dalam keadaan bersih

3. Bahan pembekuan yang direkomendasikan

4. Kondisi bokar dalam keadaan keras dan padat.

\section{Mekanisme pasar lelang}

Pasar lelang dilaksanakan dalam satu waktu, satu tempat dan satu harga. Pelaksanaan satu waktu dilakukan seminggu sekali pada Hari Minggu jam 21.00 WIB di Sekretariat APKARKUSI. Harga bokar mengalami naik turun tergantung dari kurs dan situs sicom harga karet saat ini. Mekanisme pasar lelang dimulai dari pengumpulan bokar dilakukan setiap kelompok tani atau gapoktan. Bokar diterima dilalukan uji mutu secara visual dan dibandingkan dengan standar bokar yang ditetapkan APKARKUSI, lalu diberi nama pemilik bokar. Penyampaian informasi bokar melalui grup WhatsApp paling lambat Hari Minggu jam 19.00 WIB dilanjutkan jam 21.00 WIB untuk mengadakan proses pelelangan di Sekretariat APKARKUSI. Pelelangan dihadiri oleh pengurus APKARKUSI, perwakilan kelompok tani atau gapoktan dan pedagang besar (buyer). Pengurus APKARKUSI melakukan survei harga karet hari ini dan memberitahu pedagang besar tentang harga dasar bokar. Pengurus memberikan waktu kepada pedagang besar untuk berdiskusi dengan pabrik tujuan melalui telfon seluler. Setelah berdiskusi masing-masing pedagang besar akan menuliskan harga bokar dan memberikan kepada pengurus. Harga paling tinggi yang ditawarkan pedagang yang memenangkan lelang dapat dilihat pada Tabel 1 dan Tabel 2. 
Kelompok tani atau gapoktan membawa bokar ke gudang penimbangan yang ada di Kecamatan Gunung Toar pada Hari Senin. Penimbangan dilakukan oleh perwakilan pedagang besar (buyer) yang telah ditetapkan sebagai pemenang. Persentase pemotongan dari volume bokar terhadap bokar petani sebesar 3\% untuk menanggulangi penyusutan bokar selama digudang, $1 \%$ biaya operasional dan $1 \%$ biaya yang dikeluarkan untuk pengurus kelompok tani atau gapoktan. Petani menerima uang hasil penjualan bokar pada Hari Senin jam 20.00 WIB. Untuk lebih jelas dapat dilihat pada Gambar 1 mekanisme pemasaran lelang di Kabupaten Kuantan Singingi.

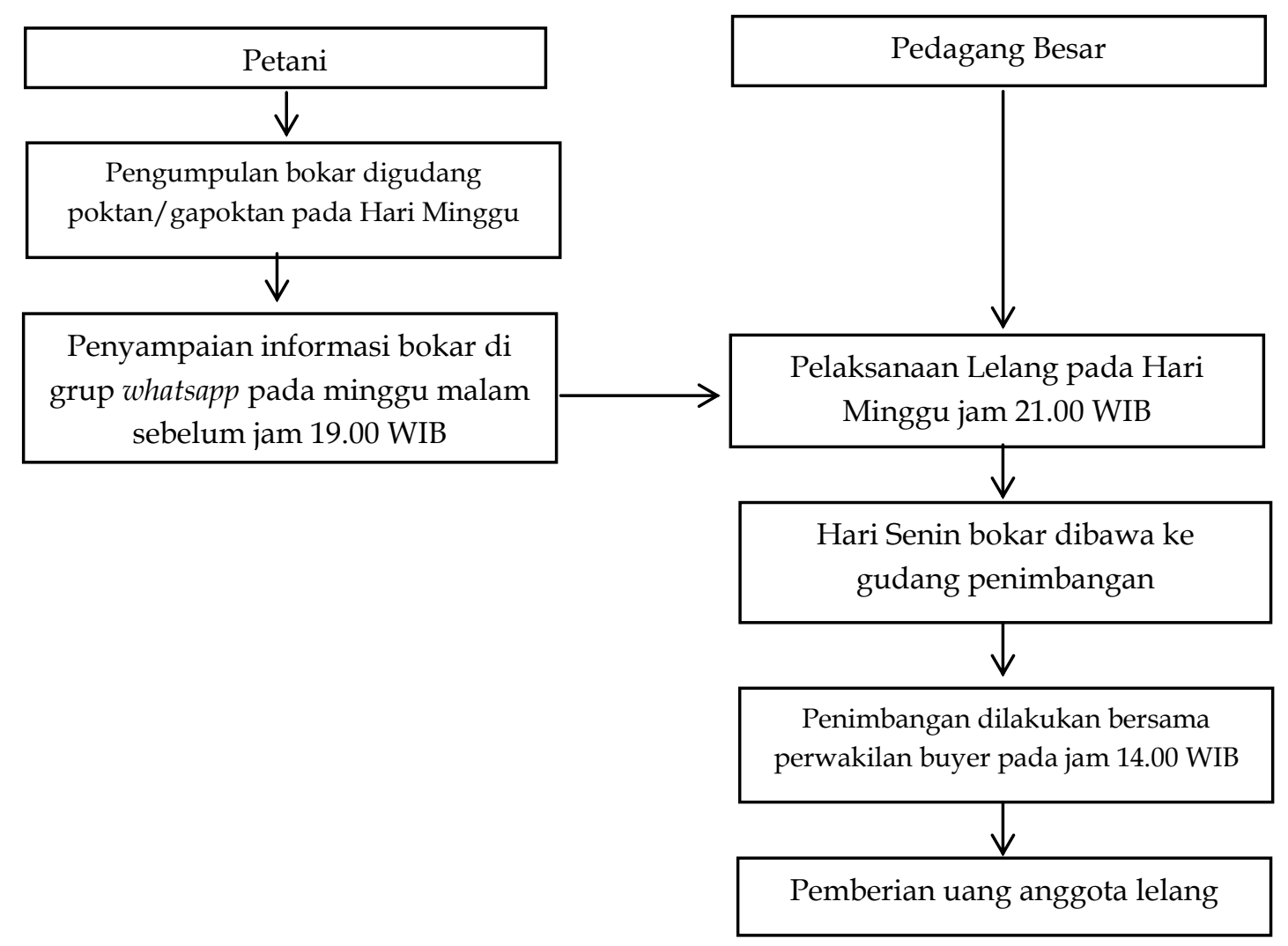

Gambar 1: Mekanisme pemasaran karet lelang di Kecamatan Kuantan Mudik

Sejalan dengan temuan Fatah (2018) yang menyatakan bahwa sistem pemasaran karet pada pasar lelang melalui gapoktan di Kecamatan Gunung Toar awalnya pada tahun 2014 bersifat tertutup. Pelaksanaan lelang diadakan disatu tempat, satu waktu dan satu harga. Mekanisme pada pasar lelang melalui gapoktan mulai dari Hari Minggu pada jam 10.00-12.00 WIB masing-masing petani membawa bokar ke tempat lelang untuk melakukan pencatatan nama dan berat bokar. Penyelenggaraan dilakukan oleh pengurus kelompok, pedagang besar dan petani yang menjual karet pada pasar lelang. Pedagang sudah menyiapkan amplop yang berisi catatan kecil mengenai harga yang mereka tawarkan dengan patokan harga dasar yang sudah ditempel terlebih dahulu. Pengurus mengumpulkan amplop dan mengumumkan kepada peserta lelang bahwa bokar ditawarkan dengan harga tertinggi dan disebutkan nama pedagang besar yang menawarkan harga tersebut. Hari Senin dilakukan penimbangan bokar petani yang mengikuti pasar lelang. Setelah selesai dilakukan penimbangan maka pembayaran hasil bokar diberikan pengurus kelompok kepada petani. 
Mekanisme yang terjadi pada lembaga pemasaran di setiap daerah berbeda-beda. Berikut bagan lembaga pemasaran yang dilalui dalam pasar lelang di APKARKUSI, Desa Sangau dan Desa Pebaun Hilir dapat dilihat pada Gambar 2.

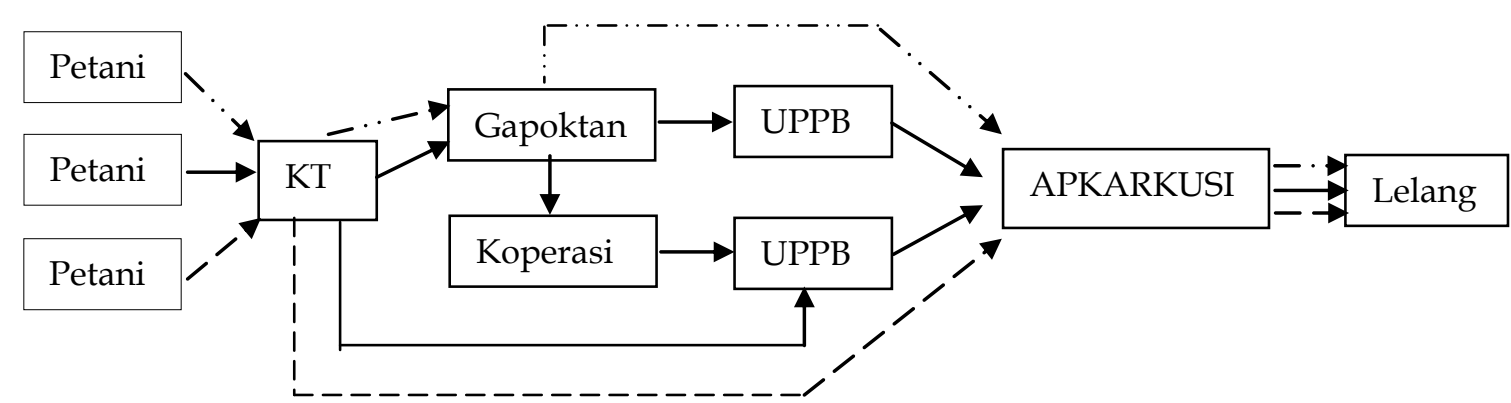

Keterangan:

Lembaga yang dilalui APKARKUSI

Lembaga yang dilalui Desa Sangau

Lembaga yang dilalui Desa Pebaun Hilir

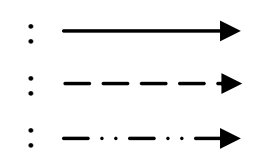

Gambar 2. Bagan lembaga pemasaran di Kabupaten Kuantan Singingi

\section{Saluran pemasaran karet pada pasar lelang}

Petani memiliki keterbatasan dalam memasarkan bokar langsung ke pabrik. Keterbatasan tersebut berupa jumlah produksi yang sedikit dan lokasi pabrik yang tidak ada di Kabupaten Kuantan Singingi. Oleh sebab itu petani membutuhkan lembaga pemasaran untuk menyalurkan hasil produksi sampai ke konsumen akhir. Panjang pendeknya saluran pemasaran berpengaruh pada harga yang akan diterima oleh petani sebagai produsen. Untuk lebih jelas dapat dilihat pada Gambar 3 dibawah.

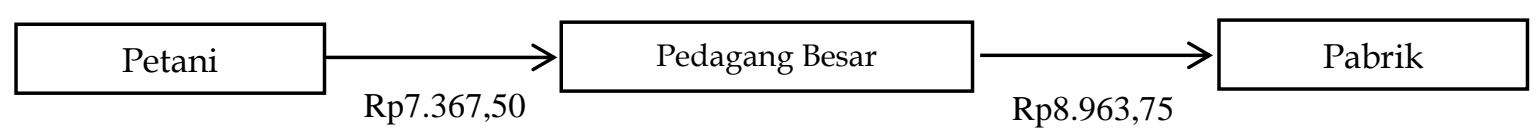

Gambar 3. Saluran pemasaran pada pasar lelang di Kecamatan Kuantan Mudik

Berdasarkan Gambar 3 dapat dilihat bawah rata-rata harga yang diterima petani Bulan Juli 2020 sebesar Rp7.367,50/kg. Pedagang besar menjual ke pabrik dengan ratarata harga Rp8.963,75/kg. Biaya pemasaran yang dibayar petani berupa persentase pemotongan dari volume bokar sebesar 5\% dan upah bongkar muat saat digudang. Biaya pemasaran ke pabrik ditanggung oleh pedagang besar dengan persentase $10 \%$ $11 \%$ dari volume berat bokar yang dijual ke pabrik.

Pasar lelang yang dilakukan tanggal 13 Juli 2020 diwakili oleh 5 pedagang besar yaitu PT. Kilang 5 Gunung diwakili oleh Pedagang 1 dengan harga bokar Rp7.280,00, PT. Teluk Luas diwakili oleh Pedagang 6 dengan harga bokar Rp7.305,00, PT. Wipolimex diwakili oleh Pedagang 2 dengan harga bokar Rp7.130,00, PT. Kapuas Besar diwakili oleh Pedagang 8 dengan harga bokar Rp7.171,00 dan PT. Batang Hari Barisan diwakili oleh Pedagang 4 dengan harga bokar Rp6.878,00. Pemenang lelang pada tanggal 13 Juli 2020 yaitu PT. Teluk Luas dengan volume bokar $4.397 \mathrm{~kg}$ seharga Rp7.305,00. Untuk lebih jelas dapat dilihat pada Tabel 1 dibawah ini. 
Tabel 1.

Nama Bayer/Pabrik dan Harga Lelang Karet

\begin{tabular}{cclr}
\hline No & Nama Buyer & \multicolumn{1}{c}{ Pabrik } & Harga Lelang (Rp/kg) \\
\hline 1 & Pedagang 1 & PT. Kilang 5 Gunung & 7.280 \\
2 & Pedagang 6 & PT. Teluk Luas & 7.305 \\
3 & Pedagang 2 & PT. Wipolimex & 7.130 \\
4 & Pedagang 8 & PT. Kapuas Besar & 7.171 \\
5 & Pedagang 4 & PT. Batang Hari Barisan & 6.878 \\
\hline
\end{tabular}

Berikut Tabel 2 pemenang lelang berdasarkan harga bokar dan volume bokar pada Bulan Juli 2020 di Kecamatan Kuantan Mudik.

Tabel 2.

Data pemenang lelang, harga bokar dan volume bokar dari Bulan Juli 2020 di Kecamatan Kuantan Mudik

\begin{tabular}{cclrr}
\hline Tanggal & Nama Buyer & \multicolumn{1}{c}{ Pabrik } & $\begin{array}{c}\text { Harga Lelang } \\
\text { (Rp/kg) }\end{array}$ & $\begin{array}{c}\text { Volume } \\
\text { Berat (Kg) }\end{array}$ \\
\hline 06 Juli 2020 & Pedagang 1 & PT. Kilang 5 Gunung & 7.110 & 4.101 \\
13 Juli 2020 & Pedagang 6 & PT. Teluk Luas & 7.305 & 4.397 \\
20 Juli 2020 & Pedagang 1 & PT. Kilang 5 Gunung & 7.455 & 2.945 \\
27 Juli 2020 & Pedagang 6 & PT. Teluk Luas & 7.600 & 4.939 \\
\hline Total & & & 29.470 & 16.382 \\
Rata-rata & & & 7.368 & 4.096 \\
\hline
\end{tabular}

Berdasarkan Tabel 2 dapat dilihat bahwa pemenang lelang dari setiap pelaksanaan pasar lelang selalu berubah tergantung pada harga yang ditawarkan pedagang besar saat lelang. Pada Bulan Juli harga bokar terus mengalami kenaikan setiap lelang. Sejalan dengan temuan Suryanto (2018) menyatakan bahwa pasar lelang diadakan seminggu sekali tepatnya pada Hari Senin. Harga yang ditawarkan pada pasar lelang berbeda-beda setiap pelaksanaan pasar lelang dan penentuan harga dasar dilakukan oleh penyuluh pertanian Kecamatan Sentajo Raya dengan melihat harga karet saat ini. Peran penyuluh pertanian Kecamatan Sentajo Raya di pasar lelang sebagai lembaga penyelenggara lelang.

Tugas pengurus APKARKUSI Kabupaten Kuantan Singingi:

1. Ketua bertugas melaksanakan dan mengawasi pelaksanaan pasar lelang dan melaporkan laporan pertanggung jawaban kepada penyuluh pertanian lepas dan Dinas Pertanian.

2. Sekretaris bertugas mencatat segala sesuatu yang berhubungan dengan kegiatan pasar lelang. Mulai dari pencatatan penawaran karet, memberi nama tiap bokar petani, mencatat jumlah bokar yang petani jual, mencatat berapa hasil yang petani dapatkan serta pembuatan laporan penjualan karet tiap minggu.

3. Bendahara bertugas pada bidang administrasi dan keanggotaan yaitu menyelesaikan semua kegiatan yang berhubungan dengan pembayaran pada pasar lelang, baik kepada pembeli, penjual maupun kepada penyelenggara lelang. 
Pelaksanaan pasar lelang dilakukan oleh APKARKUSI dengan struktur APKARKUSI dapat dilihat pada Gambar 4 dibawah.

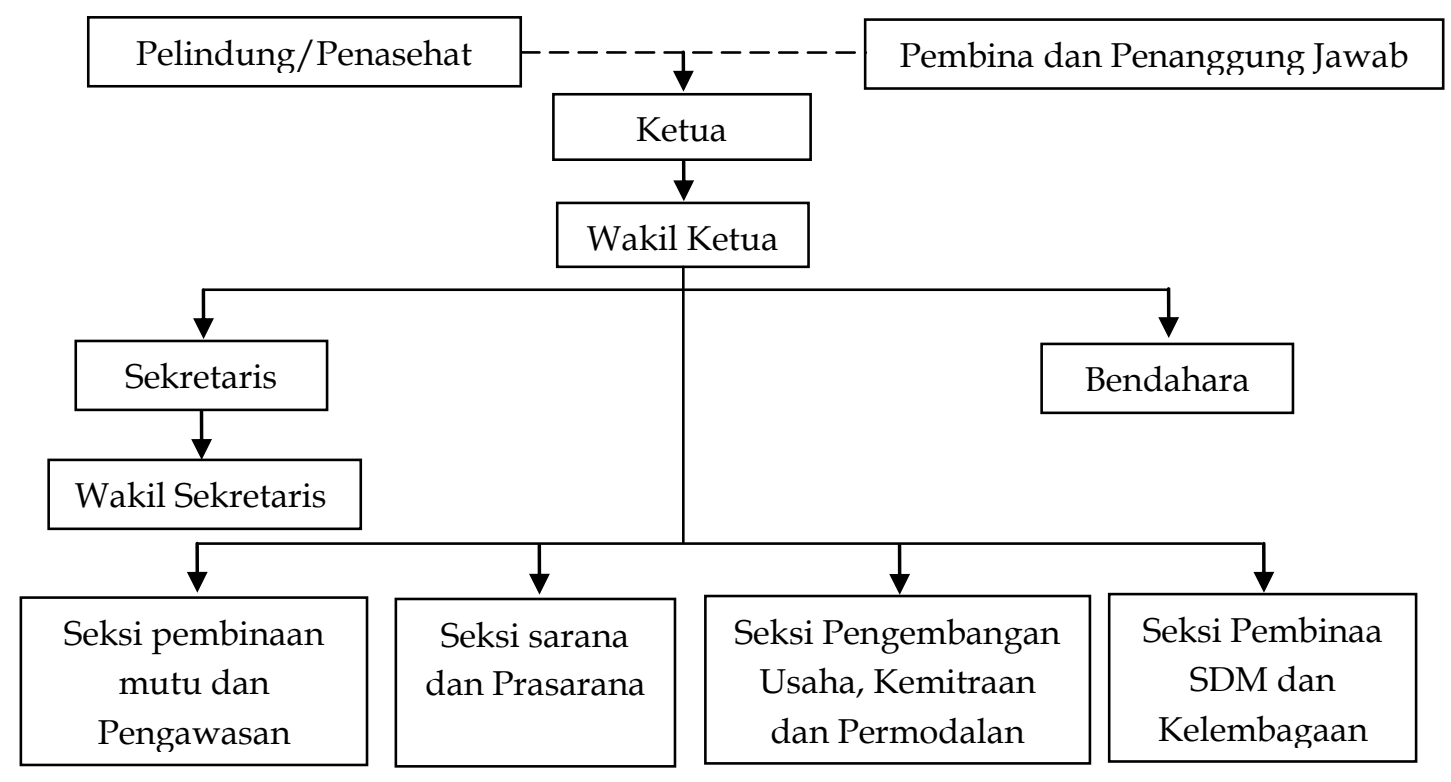

Gambar 4. Struktur APKARKUSI di Kabupaten Kuantan Singingi

\section{Analisis biaya pemasaran, margin pemasaran, keuntungan pemasaran, farmer's share, dan efisiensi pemasaran pemasaran pada pasar lelang}

Sistem pemasaran lelang di Kecamatan Kuantan Mudik merupakan pemasaran hasil perkebunan karet petani melalui kelompok tani atau gapoktan. Kelompok tani atau gapoktan berperan sebagai perantara dan membantu memasarkan bokar petani yang diadakan oleh APKARKUSI. Pasar lelang dapat menguntungkan petani karena rantai pemasaran yang dilalui petani pendek dapat dilihat lembaga pemasaran yang dilalui.

Berdasarkan Tabel 3 dapat dilihat bahwa rata-rata harga bokar Bulan Juli 2020 sebesar Rp7.367,50/kg. Biaya pemasaran yang dikeluarkan petani antara lain biaya bongkar muat Rp50,00/kg dan persentase potongan pada volume bokar sebesar 5\% artinya berat kotor dikalikan persentase yang sudah ditetapkan. Persentase pemotongan terdiri dari 3\% untuk penyusutan bokar, 1\% untuk biaya transportasi penyelenggara lelang mengantarkan bokar menuju gudang penimbangan dan $1 \%$ untuk biaya operasional kelompok tani atau gapoktan. Biaya pemasaran bokar tidak hanya dikeluarkan oleh petani, namun pedagang besar yang memenangkan lelang juga mengeluarkan biaya sampai ke pabrik. Biaya yang dikeluarkan oleh pedagang besar yaitu bongkar muat, transportasi, penyusutan dan penimbangan.

Untuk mengetahui biaya pemasaran, margin pemasaran, keuntungan pemasaran, farmer's share, dan efisiensi pemasaran dapat dilihat pada Tabel 3. 
Tabel 3.

Analisis pemasaran karet pada pasar lelang Bulan Juli 2020

\begin{tabular}{|c|c|c|c|c|}
\hline No & Uraian & $\begin{array}{c}\text { Harga } \\
\text { (Rp/Kg/Bulan) }\end{array}$ & $\begin{array}{c}\text { Biaya } \\
\text { (Rp/Kg/Bulan) }\end{array}$ & Persentase (\%) \\
\hline \multirow{7}{*}{1} & Petani & & & \\
\hline & Harga Jual & $7.367,50$ & & \\
\hline & Bongkar Muat & & 50,00 & 11,95 \\
\hline & Penyusutan (3\%) & & 221,03 & 52,83 \\
\hline & Operasional (1\%) & & 73.68 & 17,61 \\
\hline & Pengurus (1\%) & & 73,68 & 17,61 \\
\hline & Total Biaya Pemasaran & & 418,38 & 100 \\
\hline \multirow{14}{*}{2} & Pedagang Besar & & & \\
\hline & Harga Beli & $7.367,50$ & & \\
\hline & Harga Jual & $8.963,75$ & & \\
\hline & Bongkar Muat & & 100,00 & 11,13 \\
\hline & Transportasi & & 300,00 & 33,40 \\
\hline & Penyusutan (5\%) & & 448,19 & 49.90 \\
\hline & Penimbangan & & 50,00 & 5,57 \\
\hline & Total Biaya Pemasaran & & 898,19 & 100 \\
\hline & Keuntungan & 698,06 & & \\
\hline & Margin Pemasaran & $1.596,25$ & & \\
\hline & Total Biaya Pemasaran & $1.316,56$ & & \\
\hline & Total Keuntungan & 229,69 & & \\
\hline & Farmer's Share & & & 82,19 \\
\hline & Efisiensi Pemasaran & & & 14,69 \\
\hline
\end{tabular}

Petani menerima harga bokar sesuai dengan pelelangan disaat itu, hal ini berbeda dengan pasar lelang gapoktan dimana harga bokar dikurangi persentase pemotongan baru didapat harga bokar pekilo. Pasar lelang APKARKUSI pemotongan persentase dilakukan dari volume berat bokar sedangkan pasar lelang gapoktan dipotong dari harga bokar pada saat pelaksanaan lelang. Besar potongan persentase memiliki perbedaan antara pasar lelang APKARKUSI sebesar 5\% dan pasar lelang gapoktan sebesar 3\%.

Berdasarkan Tabel 3 dapat dilihat bahwa farmer's share sebesar 82,19\%. Semakin besar margin pemasaran maka bagian yang diterima petani makin kecil, begitu juga sebaliknya semakin kecil margin pemasaran maka bagian yang diterima petani semakin besar. Efisiensi pemasaran pada pasar lelang yaitu 14,69\%. Jadi selain menguntungkan memasarkan hasil perkebunan karet menggunakan sistem pemasaran lelang, pemasaran ini juga efisien.

Suryanto (2018) menyatakan bahwa potongan harga dari penyelenggara lelang atau kelompok tani yaitu sebesar 3 persen yang ditetapkan seluruh anggota kelompok tani. Adapun biaya potongan 3 persen tersebut yang digunakan untuk upah penimbangan dan angkut sebesar 1 persen, untuk pengelola kelompok tani 1 persen dan 1 persen sisanya untuk simpan pinjam apabila ingin melakukan peminjaman. Margin pemasaran adalah selisih antara harga jual awal dengan harga beli akhir, sistem pemasaran lelang memiliki rantai pemasaran yang singkat dari bokar milik petani dikumpulkan di gudang pasar lelang kemudian pedagang besar langsung membeli bokar, karena saluran pemasaran yang pendek dilakukan petani karet dalam menjual hasil perkebunan karetnya maka rata-rata margin pemasaran pada pemasaran lelang yaitu Rp.1.865,52/Kg. Persentase efisiensi pemasaran karet menggunakan sistem 
pemasaran lelang sangat baik bagi petani karena sangat efisien, efisiensi pemasaran lelang di Kecamatan Sentajo Raya berada pada angka 7\%.

\section{Kesimpulan}

Sistem pemasaran karet pada pasar lelang melalui petani-kelompok tani atau gapoktan-APKARKUSI-pedagang besar-pabrik. Mekanisme sistem pasar lelang yaitu pengumpulan bokar dilakukan setiap kelompok pada Hari Minggu di gudang masingmasing kelompok tani atau gapoktan. Bokar dilalukan uji mutu secara visual dibandingkan dengan standar bokar yang ditetapkan APKARKUSI. Lalu dibuat nama pemilik bokar dan volume bokar. Penyampaian informasi bokar di grup Whatsapp paling lambat jam 19.00 WIB. Pelelangan dilaksanakan jam 21.00 WIB di Sekretariat APKARKUSI. Rata-rata harga bokar yang diterima petani pada Bulan Juli 2020 dipasar lelang Rp7.367,50/kg. Biaya pemasaran yang dikeluarkan petani antara lain biaya bongkar muat Rp50,00/kg dan persentase potongan pada volume bokar sebesar 5\% terdiri dari 3\% penyusutan bokar, $1 \%$ untuk biaya transportasi dan $1 \%$ untuk biaya operasional. Bagian yang diterima petani (Farmer's share) sebesar 82,19\%. Efisiensi pemasaran pada pasar lelang yaitu 14,69\%. Jadi selain menguntungkan memasarkan hasil perkebunan karet menggunakan sistem pemasaran lelang, pemasaran ini juga efisien.

\section{Daftar Pustaka}

Ahmadi, N, G. F., \& Pratama, Y. (2017). Analisis Pendapatan dan Perbandingan Pendapatan Usahatani Karet Petani yang Menjual Bokar di Pasar Lelang dan Luar Pasar Lelang (Studi Kasus: KUD Manunggal Jaya Kelurahan Karang Jaya Kecamatan Pramulih Timur). Universitas Tridinanti Palembang.

Asmarantaka, R. W. (2014). Pemasaran Agribisnis. IPB Press.

BPS. (2019). Kabupaten Kuantan Singingi dalam Angka 2019.

Fatah, A. E. (2018). Analisis Keberdayaan Ekonomi Petani Karet pada Sistem Pemasaran Konvensional di Kecamatan Gunung Toar Kabupaten Kuantan Singingi. Universitas Riau.

Singingi, A. P. K. K. K. (2020). Profil Asosiasi Petani Karet Kuantan Singingi (APKARKUSI). Asosiasi Petani Karet Kuantan Singingi.

Soekartawi. (2002). Prinsip Dasar Manajemen Pemasaran Hasil-Hasil Pertanian Teori dan Aplikasinya. PT Raja Grafindo Persada.

Sudiyono, A. (2004). Pemasaran Pertanian. Universitas Muhammadiyah Malang.

Suryanto. (2018). Analisis Keberdayaan Ekonomi Petani Karet Pada Sistem Pemasaran Lelang dengan Sistem Pemasaran Konvensional di Kecamatan Gunung Toar Kabupaten Kuantan Singingi. Universitas Riau. 
Vadilla, E. (2012). Studi Pemasaran Karet dengan Mekanisme Lelang di Desa Sirih Sekapur Kecamatan Jujuhan Kabupaten Muaro Bungo. Universitas Andalas. 